\title{
EVIDENCES OF VALIDITY OF A SCALE FOR MAPPING PROFESSIONAL AS DEFINING COMPETENCES AND PERFORMANCE BY BRAZILIAN TUTORS
}

\author{
Dr. Francisco Antonio COELHO JUNIOR \\ Department of Administration, University of Brasília, BRAZIL \\ Dr. Rodrigo Rezende FERREIRA \\ Department of Administration, University of Brasília, BRAZIL \\ Dr. Tatiane PASCHOAL \\ Department of Administration, University of Brasília, BRAZIL \\ Dr. Cristiane FAIAD \\ University of Brasília, BRAZIL \\ Dr. Pedro Paulo Murce MENESES \\ Department of Administration, University of Brasília, BRAZIL
}

\section{ABSTRACT}

The purpose of this study was twofold: to assess evidences of construct validity of the Brazilian Scale of Tutors Competences in the field of Open and Distance Learning and to examine if variables such as professional experience, perception of the student's learning performance and prior experience influence the development of technical and attitudinal competences. Participants were 200 tutors (69 males and 131 females), residents in the Northeast of Brazil $(46 \%)$, aged between 18 and $56(M a g e=22, S D=8.69)$. The vast majority of tutors $(\mathbf{8 4 . 5 \%})$ exercise other professional activities or beyond the academic tutoring.

The scale consists of two factors: a) attitudinal competences and b) technical competences. Results from exploratory factor analysis provided evidence of construct validity. Additionally, results indicated that tutors who had previous experienced and who believed in the students' distance learning scored higher than those belonging to other groups (less experienced tutors and tutors who had no belief in students' learning distance learning).

Also, results indicated that those who had former experience presented a statistically higher score towards the factor "technical competences". Overall, the study underlines the necessity of adaptation and usage of such an questionnaire of competences in other global contexts, not just the Brazilian one.

The relationship between individual performance and student learning should be investigated in a cross-cultural research.

Keywords: Technical Competences, former experience, perception of student learning, individual differences, attitudinal competences. 


\section{INTRODUCTION}

The term competence is being investigated in different ways in studies related to organizational behavior, sometimes referring to an attribute of the individual, or as a variable typical of the context of organizations. Much has been discussed on the scientific literature. Especially in the field of knowledge management, authors have pointed the possibilities of application of these concepts to organizational studies (for example see Rodriguez, Patel, Bright, Gregory \& Gowing, 2002, and Teodorescu, 2006), and its objectification as an important practice of managing people in organizations (Baartman, Bastiaens, Kirschner \& Van der Vleuten, 2007).

Several Brazilian organizations has been investing heavily in the development of remote instructional systems, where the presence of tutors is essential to the full success of online learning. It is essential that these organizations have a reliable tool in order to obtain empirical data to justify any improvement actions and / or encourage the accumulation of competences oriented towards tutor performance.

The Brazilian literature on organizational behavior (for example see Meneses, Coelho Jr., Paschoal, Ferreira \& Isidro-Filho, in press) presents a profusion of studies on the mapping and analysis of competences in the context of work organizations. However, a significant proportion of those studies is theoretical, or unsystematic and prescriptive, without the proposition and empirical testing of instruments and models of management of competences. Considering these reasons, is important to develop methods and techniques required to improve the management of competences, particularly in the mapping phase, as a way of adding value to the business of the organization.

The diagnosis is even more complex when it identifies that for certain occupational positions study competences is still infancy, as is the case of tutors who work in distance education. These social actors have been widely required by Brazilian organizations, especially given the advent and consolidation of new information technologies and communication applied to business scenarios.

It is essential, therefore, considering the Brazilian context, a validated measure oriented mapping of professional competences of tutors who work in distance education modality. The objective of this work consists in proposing and empirically testing a scientifically measure oriented mapping of professional competences of 200 Brazilian tutors who work in distance education. We will show here the evidences of validity of this Brazilian scale.

The scale has validity, consistency and reliability to be used in the Brazilian organizations and should be applied in other organizations worldwide.

There is broad scientific field of the study on work applied competences (Le Deist \& Winterton, 2005; Redmond, 2013). However, there is no consensus about what, in fact, this term means, and how best to operationalize it (Jackson; Cooper-Thomas; van Gelderen; Davis, 2010).

The Brazilian literature on competence, in essence, is about concepts of delivery, complexity, adding value and job design. The concept of delivery is important, as presented by Boyatsis (2008), and so is its relationship with individual and organizational performance.

Competencies are the result of mobilization of knowledge by the individual (Campion; Fink; Ruggeberg; Carr; Philips; Odman, 2011; van der Klink, Boon, 2002). It means a combination of inputs and it expresses that individual competence when at work triggers an outcome resulting from the application of the knowledge, skills and attitudes (KSA). 
Santos, Coelho Junior and Faiad (2011) complement this definition by emphasizing that the competence at work is facilitate to the individual when developing their assignments and responsibilities effectively. Competence is about the mobilization of the individual in the use of KSA's to achieve a better performance at work.

Competence in the workplace is understood as an individual's ability to produce results in accordance with organizational or occupational goals and objectives. Thus, competencies represent synergistic combinations of knowledge, skills and attitudes expressed by the professional performance within a given organizational context and conform determined levels of exigency.

Professional competence is demonstrated by individual performance at work and involves not only the individual behavior but also includes some context variables, like emotional and material support. Professional competencies are defined by the use of benchmarks of performance. It is expected that individuals demonstrate competence through observation and analysis of their behaviors at work.

Sandberg (2000) and Carbone, Brandão, Leite and Vilhena (2009) further reinforce the French zeitgeist provided by Boyatzis, that professional skills are the set of SKAs expressed by professional performance in the organizational environment. These competences add value to both the individual and the organization and act as a bridge between the individual attributes and organizational strategy.

Professional competence refers to performance, mobilization and labor contribution to organizational strategy. In this perspective, like as Le Boterf and Zarifian discussed, the concept of competence is thought of as a set of knowledge, skills and attitudes that justify a high performance and superior signal quality.

Professional competences are exercised when individuals act in work contexts, serving as a bridge between their behaviors and organizational strategy. Thus, competences can add economic and social value to individuals and organizations. As their contribution to the organizational objectives are achieved and to be socially recognized the capacity of individuals, teams and organizations. The skills here shall be construed as technical, linked to the performance of the duties of the guardian, and behavioral, affective and attitudinal nature. More information about the mapping of the competences can be found in Coelho Junior, Faiad, Borges e Rocha (2013).

Considering the occupational role of the Brazilian tutors it is expected that they have the expertise required to use the virtual learning environment (VLE) and that they excel in the use of new technologies of communication and information. Furthermore, they are expected to be friendly with students and with the other social actors involved in distance learning.

\section{METHOD AND PROCEDURE}

\section{Participants}

The sample consisted of 200 tutors (69 males and 131 females), residents in the Northeast of Brazil $(46 \%)$, aged between 18 and $56\left(M_{a g e}=22, S D=8.69\right)$. The vast majority of tutors $(84.5 \%)$ have other professional activities or beyond the academic tutoring. It was also identified also that 187 individuals, or $\mathbf{9 3 . 5} \%$, had some type of training to act as a tutor in distance education. In addition, for the purposes of the study, the sample was divided into groups according to the Professional experience and perception of the students learning performance. 
Table: 1

Demographic characteristics of the sample

\begin{tabular}{|c|c|c|c|c|c|c|c|c|}
\hline \multicolumn{2}{|c|}{ Sex } & $\begin{array}{l}\text { Time job } \\
\text { as a tutor }\end{array}$ & \multicolumn{3}{|c|}{$\begin{array}{c}\text { Have you been } \\
\text { trained to be a } \\
\text { tutor? }\end{array}$} & \multicolumn{3}{|c|}{$\begin{array}{l}\text { Do you think the } \\
\text { student of } \\
\text { distance } \\
\text { education learn? }\end{array}$} \\
\hline $\begin{array}{l}\text { Men } \\
\text { Women }\end{array}$ & $\begin{array}{l}34,5 \% \\
65,5 \%\end{array}$ & $\begin{array}{lll}<-1 & 54 & 27,5 \% \\
1-3 & 113 & 56,5 \% \\
>-3 & 32 & 16 \%\end{array}$ & $\begin{array}{l}\text { Yes } \\
\text { No }\end{array}$ & $\begin{array}{r}187 \\
13\end{array}$ & $\begin{array}{l}93,5 \% \\
6,5 \%\end{array}$ & $\begin{array}{l}\text { Yes } \\
\text { No }\end{array}$ & $\begin{array}{r}188 \\
1\end{array}$ & $\begin{array}{r}94 \% \\
6 \%\end{array}$ \\
\hline
\end{tabular}

\section{Characteristics of the Questionnaire and Steps of Construction}

The first version of the scale was built considering Brazilian empirical reports on competencies and according to the international literature.

The construction of the measure of professional tutor competence occurred in a series of workshops with Brazilian tutors who had already worked in distance education. We conducted 24 semi-structured interviews (individual and focus groups) with tutors teachers who worked at the undergraduate and specialization levels with the Open University of Brazil (a national Brazilian government program) within the University of Brasilia/Federal District. These interviews were made in order to conduct the survey of professional competence.

Open University of Brazil is a national Brazilian Program offered by the Government. It is a consolidated system for public universities that was implemented in 2006. The OUB offers higher level courses to the Brazilian community by the open modality, mainly for sections of the population who have difficult access to classroom education or to graduate school.

We tried to identify the competences and knowledge required to accomplish tasks. It was asked of each interviewee that they recount critical incidents or difficulties they faced in the course of their work and what steps they took for the resolution of those.

\section{Procedures}

All participants were informed of the objectives of this work and gave informed consent for their spontaneous participation. The information has been processed in confidential and anonymous way, and individuals were informed of the interviews, individual or in group, would be recorded for specific use in research.

The content analysis allowed the extraction of information that led to the mapping of technical and behavioral competencies expected in competent performance of the function of mentoring for individuals who work in distance education. We used the recommendations of two acknowledged Brazilian researchers, Brandão and Bahry (2005), for identifying and building competences (aggregate a verb, a condition and a measurable criterion of performance). We constructed a first version of a fully structured questionnaire for online application considering the content analysis made. The items of the instrument were analysed as to their accuracy, reliability, clarity, parsimony and objectivity. A thorough analysis of the instructions for instrument use was performed to avoid bias in the interpretative guidelines of the instrument, which could hinder the fulfillment of this.

Due to the difficulty of obtaining a random Brazilian sample we opted for convenience and affordability sampling. First of all we chose to send these emails only to tutors who worked 
in distance learning courses (undergraduate Public Administration, post-graduate in Public Management and post-graduate in Healthcare Management courses) offered by the Department of Administration at University of Brasília. We used a database containing the names and emails of the tutors. Data were stored in a database and procedures of exploratory factor analysis (internal consistency, exploratory factor analysis, reliability and variance explained, among others) were performed. The structure of the scale considers the empirical analysis of the main components, as well as analysis of multicollinearity and factorability matrix. Extent of intercorrelation was considered -above 0.30, distribution of eigenvalues-scree plot, Bartlett 's sphericity test- AIC, with $\mathbf{p}<0.001$ and analysis of KMO. Subsequently Principal Axis Factoring (PAF) method was used, with oblique rotation (direct oblimin) to verify the correlations between factors, proceeding to the calculation of factor scores.

It is noteworthy that there are different types of criteria for determining the number of factors, which may be reduced to three: statistical criteria (by tests of significance), conventional criteria and the theoretical relevance of the component or factor. These three previous criteria were used together with other criteria for factor determining the matrix: eigen values $>1$, minimum of $3 \%$ of the variance explained, scree plot, determination of loads and factor scores $(>0.32$ ), analysis correlation factor (greater burden than 0.30 indicates a trend of clustering factors), analysis of internal consistency (Cronbach's alpha) and finally interpretability of the empirical solutions.

\section{RESULTS}

\section{Factor Analysis of the Competence Questionnaire}

For the examination of the structural validity of the competence questionnaire, a main principal axis factoring analysis of the main axes was used. Some items are exemplified in table: 2.

Table: 2

Empirical structure of the competence questionnaire

\begin{tabular}{|c|c|c|}
\hline Example of Questions & $\begin{array}{l}\text { Attitudinal and } \\
\text { Behavior } \\
\text { Competences }\end{array}$ & $\begin{array}{c}\text { Technical } \\
\text { Competence } \\
\text { s } \\
\end{array}$ \\
\hline $\begin{array}{l}\text { Ability to act with flexibility (adjust me, appropriately, } \\
\text { the new facts, concepts or situations) }\end{array}$ & ,75 & \\
\hline $\begin{array}{l}\text { Ability to act with versatility (I adjust myself to } \\
\text { new situations, adapting myself to various circumstances) }\end{array}$ & ,73 & \\
\hline $\begin{array}{l}\text { Ability to act with ethics and professional behavior (act } \\
\text { with decency, honesty and integrity, according to } \\
\text { moral and ethical standards established). }\end{array}$ & ,72 & \\
\hline $\begin{array}{l}\text { Ability to act with initiative (propose solutions } \\
\text { and/or act immediately and effectively in a situation) }\end{array}$ & ,69 & \\
\hline $\begin{array}{l}\text { Ability to act proactively (envision situations, } \\
\text { seeking solutions to problems or conflicts). }\end{array}$ & ,69 & \\
\hline $\begin{array}{l}\text { Apply exercises students, correcting them } \\
\text { in a timely manner. }\end{array}$ & & ,76 \\
\hline $\begin{array}{l}\text { Identify the student's question, in the discussion } \\
\text { forums or at other times in order to make clear } \\
\text { answers to the questions posed in order to } \\
\text { optimize the tutor-student interaction }\end{array}$ & & 76 \\
\hline $\begin{array}{l}\text { I demonstrate mastery of the content to be taught } \\
\text { in order to better answer the doubts and } \\
\text { questions of the students. }\end{array}$ & & ,76 \\
\hline $\begin{array}{l}\text { I have ability to seek, in the literature, related } \\
\text { to discipline theory, enabling me to research and }\end{array}$ & & 69 \\
\hline
\end{tabular}


answer any questions students with readiness and agility

I am able to motivate the student, providing

,68

feedback (negative and / or positive) answers

to all exercises, chats and forums

\begin{tabular}{ccc}
\hline Total number of questions & 44 & 24 \\
\hline Total Variance Explained & $33,4 \%$ & $6,26 \%$ \\
\hline Eigenvalue & 23.380 & 4.385 \\
\hline Cronbach's Alpha & 0.96 & 0.93 \\
\hline
\end{tabular}

\section{Reliability Analysis}

In table: 2, there is a concise presentation of the reliability control results, concerning the competence questionnaire. The analysis showed that in relation to Attitudinal and Behavior Competences the Alpha Cronbach coefficient was .96 and in relation to technical competences a Cronbach coefficient was .78. The results indicated that the questions in both factors had a very satisfying internal cohesion.

\section{Variance Analyses for Independent Samples Towards More Than One Factors}

From the variance analysis towards two independent factors, the "Professional experience" and "perception of the student's learning performance", there appeared to be statistically important interaction between them and the attitudinal $\left(F_{3,020}=0.153 ; p=0.003<0.05\right)$ and technical competences $\left(F_{3,608}=0.258 ; p=0.001<0.05\right)$. The anova multiple comparison that the tutors who had previous professional experience believed in students' learning through distance education scored higher than tutors belonging in the other groups (less experienced tutors, and tutors who had little or no belief in students' learning through distance education).

\section{T-test Analyses for Independent Samples}

To check whether there were statistically important differences towards the two competence factors "attidunal/behavior" and "technical", owed to former experience of the participants tutoring distance education, T-tests for independent samples, were performed. The results indicated that former experience constitutes a differentiation element towards the factor "technical competence" (table 3).

Table: 3

Control of the differences between the factors "attitudinal/behavior competences" and "technical competences" in relation to former experience tutoring in distance education

\begin{tabular}{|c|c|c|c|}
\hline Factors & T & df & P \\
\hline $\begin{array}{c}\text { Attitudinal/Behavior } \\
\text { Competences }\end{array}$ & -.69 & 198 & .009 \\
\hline Technical Competences & -.76 & 198 & .002 \\
\hline
\end{tabular}

From the means, it was indicated that those who had former experience presented a statistically higher score $(M=4.5, S D=.41)$ towards the factor "technical competences" in relation to those who did not $(M=4.3, S D=.55)$.

\section{DISCUSSION}

The scale oriented by mapping professional competences of Brazilian tutors proved to be a reliable and valid measure. It may allow for the investigation of the issues related to the operation and use of new tutoring skills in the workplace. 
A suggestion for future research concerns the development of a measurement instrument specifically dedicated to the identification of psychosocial factors expressed by Brazilian tutors and students studying at distance modality. An important variable, for example, concerns the attitude of these social actors against the distance education.

We hypothesize that positive attitude towards distance learning can stimulate the commitment on the part of both tutors and students, promoting the maximization of learning. In addition values, strategies for teaching, learning and commitment to distance education also deserve to have constructed and validated measures along the lines of this article. We hypothesize that they can help to explain the acquisition of competences and performance of both (tutors and students).

It is recommended that a scale to measure the problems of transfer of learning or obstacles to retention and transfer of new knowledge and competences in students' activities be created. Qualitative methodology can even be an interesting technique in this sense, since it could be used to further investigate the behaviors related to inhibition of usage of knowledge acquired via distance education.

Another variable that can be incorporated into studies Brazilian tutors' competences refers to the support provided to learning and transfer. Support explains significant portion of the variability of transfer of formal or informal learning, measured in terms of impact of the content learned in the subsequent performance.

It is imperative, therefore, that the environment in which the tutor performs their tasks and the degree of support provided to learning among students be scientifically studied. It is indispensable to study the factors that facilitate implementation of contents learned in distance education.

Among the contributions of this study is that of building and validating a Brazilian scale that can be used in different contexts of evaluation of distance learning. We believe that mapping the professional skills of the tutors can also help improve the academic and pedagogical management systems courses this type of modality, hence improving students' performance.

Another contribution concerns the proposition of a consolidated variable in the Brazilian literature on organizational behavior, competences, applied to an innovative teaching method whose boundaries seem to be endless in their global reach. The measure even can be a starting point to cover similar gaps in organizational literature from other countries. The methodology of data collection, entirely conducted through remote means by e-mail in all regions in Brazil, can also be considered an important contribution of this study.

\section{BIODATA and CONTACT ADDRESSES of the AUTHORS}

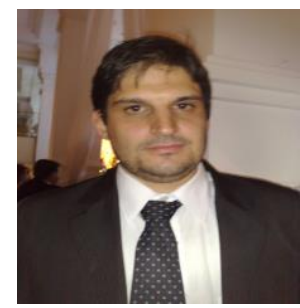

Francisco Antonio COELHO JUNIOR, Ph.D. is a Professor in the Department of Administration at University of Brasília in Brazil. His main area of interest and research is Organizational Behavior and Multilevel Modeling. He teaches the undergraduate courses of Administration and Public Policy Management, as well as the graduate course of Administration at University of Brasília/Brazil.

Francisco Antonio COELHO JUNIOR, Assistant Professor, Department of Administration University of Brasília Faculty of Administration, 
Contability and Economic Sciences, 70910-900, Brasília, BRAZIL

Phone: +55613107-0758

Email(s): acoelho@unb.br fercoepsi@gmail.com

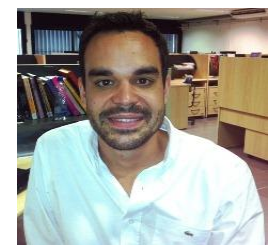

Rodrigo Rezende FERREIRA, Ph.D. is a Professor in the Department of Administration at University of Brasília in Brazil. His main area of interest and research is Quality of Life at Work and Training Needs Assessment. He teaches the undergraduate course of Administration at University of Brasília/Brazil.

Professor, Department of Administration

University of Brasília Faculty of Administration,

Contability and Economic Sciences, 70910-900, Brasília, BRAZIL

Phone: +55613107-0758

Email: ferreirarods@gmail.com

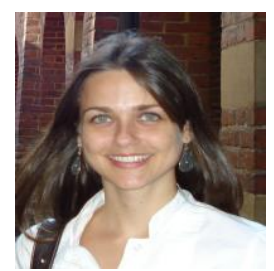

Tatiane PASCHOAL, Ph.D. is Professor in the Department of Administration at University of Brasília in Brazil. Her main area of interest and research is Quality of Life at Work, Well-Being at Work and Human and Organizational Values. She teaches the undergraduate course of Administration at University of Brasília/Brazil.

Professor, Department of Administration

University of Brasília Faculty of Administration, Contability and Economic Sciences, 70910-900, Brasília, BRAZIL

Phone: +55613107-0758

Email: tatipas@yahoo.com

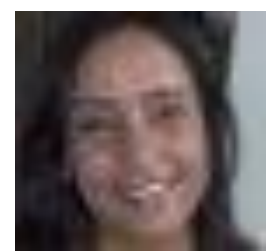

Cristiane FAIAD, Ph.D. is a Manager for the Area of Psychological Assessment in the Center of Selection and Events Promotion at University of Brasilia. Her main area of interest and research is Psychological Assessment, Profissiografic and Human Competences Analysis and Job Design for Public Safety in Brazilian Organizations.

\section{Cristiane FAIAD}

Ph.D. a Manager for the Area of Psychological

Assessment in the Center of Selection and

Events Promotion at University of Brasilia, BRAZIL

Email: crisfaiad@gmail.com

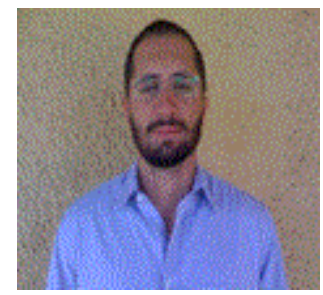

Pedro Paulo Murce Meneses, Ph.D. is a Professor in the Department of Administration at University of Brasília in Brazil. His main area of interest and research is Policies and Practises of Human Resources and Training at Work. He teaches the undergraduate course of administration, as well as the graduate course of Administration at University of Brasília/Brazil. 
Assistant Professor, Department of Administration

University of Brasília Faculty of Administration,

Contability and Economic Sciences, 70910-900, Brasília, BRAZIL

Email: pemeneses@yahoo.com

Acknowledgments of the Authors: The authors thank CNPq for financially supporting this study.

\section{REFERENCES}

Baartman, L. K. J., Bastiaens, T. J., Kirschner, P. A. \& Van der Vleuten, C. P. M (2007). Evaluation assessment quality in competence-based education: a qualitative comparison of two frameworks. Education Research Review, 2, 114-129.

Boyatsis, R. E. (2008). Competencies in the 21st century. Journal of Management Development, 2オ(1), 5-12.

Brandão, H. P., \& Bahry, C. P. (2005) "Gestão por competências: métodos e técnicas para mapeamento de competências (Competency management: methods and techniques for mapping competences)". Revista do Serviço Público, 56(2).

Campion, M. A.; Fink, A. A.; Ruggeberg, B. J.; Carr, L.; Philips, G. M. \& Odman, R. B. (2011). Doing competencies well: best practices in competency modeling. Personnel Psychology, 64, 225-262.

Carbone, P. P., Brandão, H. P., Leite, J. B. \& Vilhena, R. M. (2009). Gestão por competências e gestão do conhecimento (Competency and knowledge management). Rio de Janeiro: Fundação Getúlio Vargas.

Coelho Junior, F.A., Faiad, C., Borges, J.P.F. \& Rocha, N. F. (2013). Mapeamento de competências profissionais de tutores de cursos na modalidade a distância (Mapping of professional competences of tutors of courses in distance modality). Estudos e Pesquisas em Psicologia, 13(3).

Jackson, D. J. R., Cooper-Thomas, H. D., van Gelderen, M. \& Davis, J. (2010). Relationships among developmental competency measures and objective work outcomes in a New Zealand retail context. Human Resource Development Quarterly, 21(2), 169-186.

Le Deist, F. D., \& Winterton, J. (2005). What is competence?. Human Resource Development International, $8(1)$, 27-46.

Redmond, E. (2013). Competency models at work: the value of perceived relevance and fair rewards for employee outcomes. Human Resource Management, 52(5), 771-792.

Rodriguez, D., Patel, R., Bright, A., Gregory, D., \& Gowing, M. K. (2002). Developing competency models to promote integrated human resource practices [Special issue: Human resources management in the public sector]. Human Resource Management, 41(3), 309-324.

Sandberg, J. (2000). Understanding Human Competence at Work: an Interpretative Approach. Academy of Management Journal, 43(1), 9-25.

Santos, F. A. S., Coelho Jr., F. A. \& Moura, C. (2011). Análise crítica da produção científica brasileira sobre competências em periódicos da área de Administração entre 2005 e 2010 (Critical analysis of the Brazilian scientific production on competences in Administrations 
journals between 2005 and 2010). Anais. Anais do XXXV Encontro Nacional da Associação Nacional de Pós-Graduação e Pesquisa em Administração, Rio de Janeiro.

Teodorescu, T. (2006). Competence versus competency: What is the difference? Performance Improvement, 45(10), 27-31.

van der Klink, M., \& Boon, J. (2002). The investigation of competencies within professional domains. Human Resource Development International, 5(4), 411-424. 